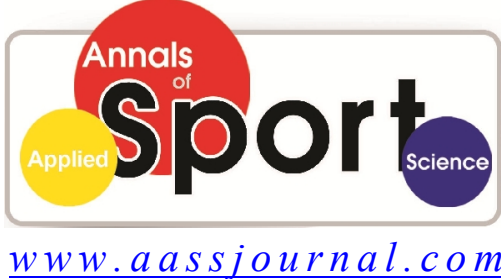

ISSN (Online): 2322 - 4479

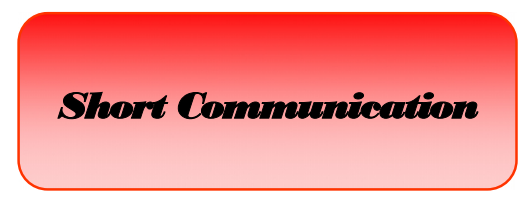

Received: 09/01/2014 Accepted: 03/04/2014

\title{
Preference of Educational Philosophy and Philosophical Mindedness of Iranian Physical Education and Sport Science Lecturers
}

\section{${ }^{1}$ Fatemeh Ghorbanalizadeh Ghaziani, ${ }^{2}$ Seyed Mohammad Hosein Razavi, ${ }^{3}$ Siavash Khodaparast Sareshkeh ${ }^{*},{ }^{4}$ Rohollah Ghasemi}

1. Tehran North Branch, Islamic Azad University, Tehran, Iran.

2. Faculty of Physical Education and Sport Sciences, Mazandaran University, Babolsar, Iran.

3. Departement of Physical Education and Sport Sciences, Lahijan Branch, Islamic Azad University, Lahijan, Iran.

4. Ayatollah Amoli Science and Research Branch, Islamic Azad University, Amol, Iran.

\begin{abstract}
The aim of this study was to investigate educational philosophy and philosophical mindedness of Iranian physical education and sports science lecturers (state-run Universities and Islamic Azad Universities). 150 questionnaires were randomly distributed among them, 123 filled questionnaires returned and finally 98 were confirmed. Two major instruments of Philosophy Preference Assessment (PPA) constructed by Wiles and Bondi (2010) with Cronbach's alpha = 0.859, and Philosophical Mindedness (PM) constructed by Soltani (1996) with Cronbach's alpha $=0.86$ based on Smith model were used to examine the research hypotheses. The results showed that experimentalism and realism were the first and second educational philosophy of Iranian physical education lecturers, respectively $(\mathrm{p}=0.001)$. Also, comprehensiveness, penetration, and flexibility are the first, second, and third philosophical mindedness preference, respectively $(\mathrm{p}=$ 0.001). It is difficult for many people to build their beliefs based on a philosophical thought and special philosophical principles; therefore eclecticism is the combination of concepts from philosophical aspects in form of a harmonic belief. Thoughtful combination of beliefs builds a mature philosophical viewpoint. Also, it seems that it is necessary for lecturers to have comprehensiveness, penetration, and flexibility equally and consonantly, so we can say that they were equipped with philosophical mindedness.
\end{abstract}

Key Words: Experimentalism, Realism, Comprehensiveness, Penetration, Flexibility.

Corresponding Author:

Siavash Khodaparast Sareshkeh

E-mail: s.khodaparast@yahoo.com 


\section{INTRODUCTION}

Teachers and education philosophy are important components in any teachinglearning process (1), and a teacher's philosophical preferences affect his/her preferences for teaching-learning, personality characteristics, attitudes, values, and competencies (2). On one hand, various philosophical and mental schools have stressed different forms of educational centers and their educational roles in these places. Philosophy plays a key role in direction of humankind and effective application of acquired knowledge and skills during professional internship (3).

On the other hand, the thought is an important issue of education, as thought and skill of proper thinking have been occupying the mind of scientists for a long time (4). In other words, since education is today known as the most basic factor of growth and improvement of culture, politic, economic and society, the most important responsibility of educational officials (managers, teachers, and university lecturers) (5), therefore, their thought ability in order to improve the educational quality is considered as the most important characteristics of them; thus, proper and logical thought of educational lecturer depends on philosophical mindedness. Philosophical mindedness of a person depends on his/her ideology, problem coping, and thought characteristics that are coming eyes in various aspects of his/her behavior. Philosophical mindedness gives insights and knowledge to anyone to protect his/her from narrow-mindedness, selfcenteredness, and unilateralism in coping with problems, and also helps his/her make logical decision for all works (4).

John Dewey believes that education should be offered in practice and in physical education and sport, the issue of body's and mind's growth and improvement, human's motor behavior and skills is rooted in practical education and training (3), and because of special importance of physical education and sport science in practical education and in cultural, political, economic and social growth and improvement, it elevated the responsibility of educational officials of this field. So the main question of this study is, "what are the preferences of educational philosophy and philosophical mindedness of Iranian physical education and sports science lecturers as key element for scholar system of sport?"

Literature review in this issue shows that it is inadequate and has contradictory results (2, 4-18). Safania, Ghorbanalizadeh Ghaziani, and Tayebi (2010) and Safania (2011) found that educational philosophy preferences changed from idealism to realism induced by 16 sessions of teaching principles and philosophy of physical education, and acceptation levels of students to educational philosophies of perennialism, realism and idealism elevated significantly after 16 sessions of teaching (13). Also, the levels of philosophical mindedness and its two dimensions include "penetration" and "comprehensiveness" increased significantly after teaching principles and philosophy of physical education. But the dimension of "flexibility" didn't change significantly (4). Doganay and Sari found that there were no significant differences between teachers' educational philosophies and their genders, type of school they graduated from, experience, and branch. It is also found that there are no consistency between teachers' views about aims and content of education, teaching - learning environment and teachers and students roles in teachinglearning process and their primary preferences of educational philosophies (6).

Therefore the aim of this study is to investigate educational philosophy and philosophical mindedness preferences of Iranian physical education and sports science lecturers. 


\section{MATERIALS AND METHODS}

Total number of 150 questionnaires was randomly distributed among Iranian lecturers of physical education and sports science (state-run universities and Islamic Azad Universities), 123 filled questionnaires returned and finally 98 were confirmed. Two major instruments of Philosophy Preference Assessment (PPA) constructed by Wiles and Bondi (2010) (17), and Philosophical Mindedness (PM) constructed by Soltani (1996) (19) based on Smith model were used to examine the research hypotheses. Some demographic questions are also included in the questionnaire which are mentioned in the below. Five dimensions of PPA (Cronbach's alpha $=0.859$ ) were measured in this study: Perennialism, Idealism, Realism, Experimentalism, and Existentialism. All of the measures of PPA used a 5-point Likert-type scale with response categories $(1=$ Strongly Disagree; $5=$ Strongly Agree). Also, three dimensions of PM (Cronbach's alpha = 0.86) were measured in this study: Comprehensiveness, Penetration, and Flexibility. All of the measures of PM used a 4point Likert-type scale with response categories $(1=$ Never; 4 = Ever $)$. There were no contrary scored items in the measures of PPA and PM. The repeated measure of ANOVA applying SPSS software used to examine the preferences of educational philosophy and philosophical mindedness of Iranian physical education and sports science lecturers.

\section{RESULTS}

According to repeated measure of ANOVA, there was a significant preference $(\mathrm{F}$ $=76.33, \mathrm{p}=0.001$ ) in educational philosophy of Iranian lecturers of physical education and sports science (graph 1). Pairwise comparison based on main effects of Bonferroni adjustment showed that there was a significant difference between realism with prennialism and existentialism $(p<0.05)$, significant difference between experimentalism with
Prennialism, existentialism $(\mathrm{p}<0.01)$ and Idealism $(\mathrm{p}<0.05)$.

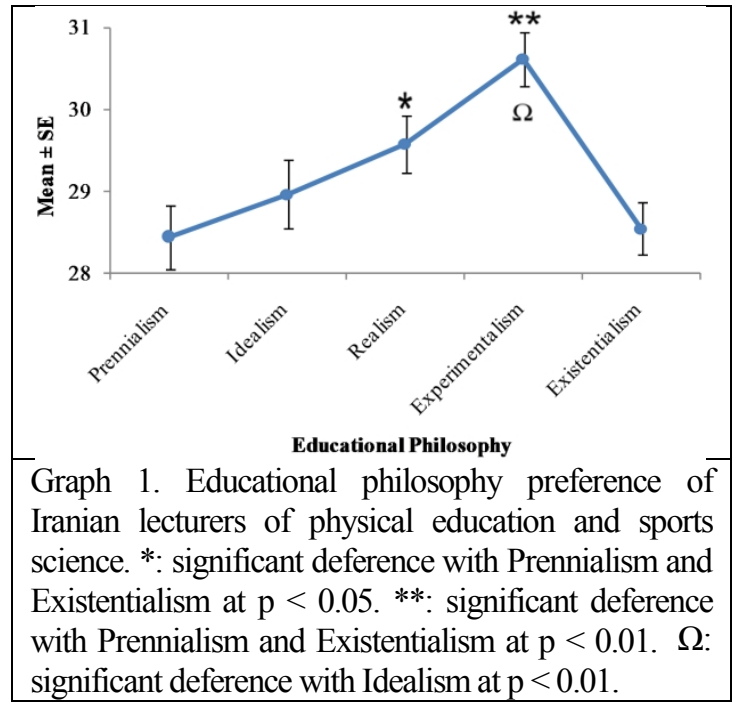

According to repeated measure of ANOVA, there was a significant preference $(\mathrm{F}=124.35, \mathrm{p}=0.001)$ in philosophical mindedness of Iranian lecturers of physical education and sports science (graph 1). Pairwise comparison based on main effects of bonferroni adjustment showed that there was significant difference between penetration and flexibility with comprehensiveness $(\mathrm{p}<0.01)$, also significant difference between flexibility with penetration $(\mathrm{p}<0.01)$.

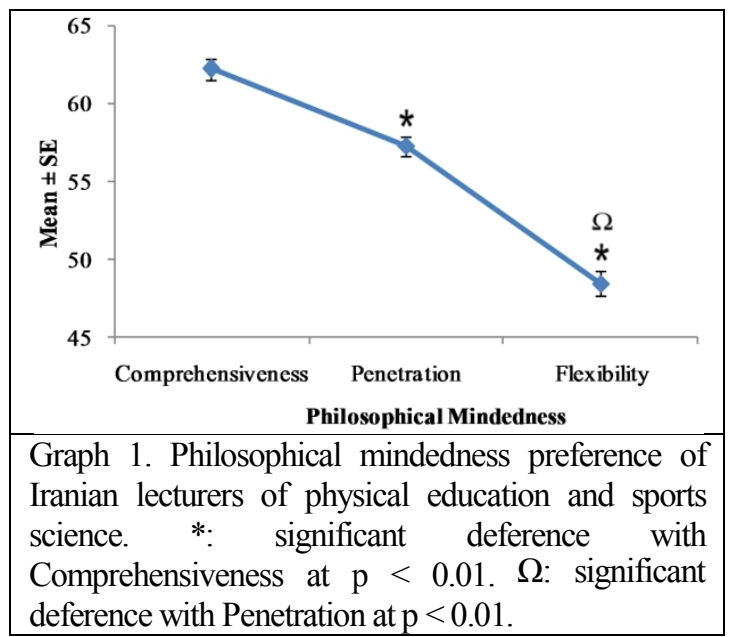




\section{DISCUSSION and CONCLUSION}

We observed that experimentalism was the first educational philosophy preference of Iranian physical education lecturers. In this philosophical school, educational programs are based on growth and development, and teaching methods are based on problem-solving and research, evaluation is based on research, while classroom managing is a personal presence, and the role of teacher is adviser and contributor of students $(1,17)$ as it is applied in sports science (3).

Besides, educational philosophy of realism had the second preference among Iranian physical education lecturers. In this philosophical school, material or physical world is the real world, and it can be achieved better to reality through scientific ways (3). Schools have to teach students that the world is what is, time and place of current world, and truly and really issues. Schools must manage with highly discipline, student receives all type contents of studies and investigations inactively and the learning process is evaluated observationally (17).

It is difficult for many people to build their beliefs based on a philosophical thoughts and special philosophical principles; therefore, eclecticism is the combination of concepts from philosophical aspects in the form of a harmonic belief. Thoughtful combination of beliefs build a mature philosophical viewpoint (17). In this study, there is not an equal and consonant status in dimensions of educational philosophy of lecturers as eclecticism. So they must try to improve their prennialism, idealism, realism, existentialism, and experimentalism in coordination together.

Regarding philosophical mindedness, we saw that comprehensiveness have the first preference, which means that the lecturers consider the world's phenomenon in an organism, so that all elements of it are tightly related. They look to special issues in relation to comprehensive basis; they concern the temporary problems to long term aims; they apply universalization/popularization ability, and they are patient all the time $(4,5,8,14,16)$.

Also penetration has the second preference among Iranian physical education lecturers. In other words, they consider beyond of issues with asking about axiom, discovery and expression basics, problems, and assumptions at every situation, applying sensibility with regard to basic aspects, relating the outlooks on inductive assumptions (4, 5, 8, 14, 16). But Iranian lecturers of physical education have lower flexibility as the third preference rather than two other dimensions. Flexibility is mindedness that surrounds the ability of logical acceptance of new methods and ways created in world of manufacture, work, and technology, and also avoidance from inadvisable resistance to these changes. Lecturers with flexibility leave one from mental hardness, evaluate opinions and viewpoints, apart from its sources, attend to various aspects of problems and develop assumptions, explanations, and viewpoints, accept provisional, conditional and interesting judgments $(4,5,8,14,16)$.

It seems that it is necessary for lecturers to have comprehensiveness, penetration and flexibility equally and consonantly, so we can say that they were equipped with philosophical mindedness. In this study there is not an equal and consonant status in dimensions of philosophical mindedness. Therefore, they have to try improving their comprehensiveness, penetration, and flexibility in coordination together.

\section{REFFRENCES}

1. Erkiliç TA. Importance of Educational Philosophy in Teacher Training for Educational Sustainable Development. Middle-East Journal of Scientific Research. 2008;3(1):01-8. 
2. Duman B. Correlation between the graduate-students' perception of educational philosophies and their democratic attitudes. Procedia - Social and Behavioral Sciences. 2010;2(2):5830-4.

3. Wuest D, Bucher C. Foundations of Physical Education, Exercise Science, and Sport: McGraw-Hill Companies,Incorporated; 2008.

4. Safania AM. Study the Effect of Training of Principles and Philosophy of Physical Education on Students' Philosophy Mindedness. Quarterly Educational Psychology. 2011;7(21):45-55[Article in Farsi].

5. Damarchili F, Rasoulnezhad AAH. The Relationship between Philosophic-Mindedness and Creativity among Faculty Members of IAU Zanjan Branch. The Journal of Modern Thoughts in Education. 2009;4(1):45-62[Article in Farsi].

6. Doganay A, Sari M. Evaluation of Elementary School Teachers' Perceptions about Their Own Educational Philosophies.

7. Doganays A. The Effect of PreŌService Teacher Education on the Educational Philosophies of Prospective Teachers. Education and Science. 2011;36(161):332-48.

8. Javidi K, Jafarabadi,T., Aboutorabi R. Philosophical Mindedness and Leadership Styles in Higher Education: The Case of Ferdowsi University of Mashhad. Studies in Education \& Psychology. 2010;11(1):211-34[Article in Farsi].

9. Khaledan A, Abkar AR. Investigation of Philosophical Mindedness of Coaches and it's relationship with some Demographic Factors. Journal of sports sciences. 2005;1(1):1-15[Article in Farsi].

10. Nazem F, Yadegari F, Hasoumi T, Ghaedmohammadi MJ. Philosophical Mindedness of Managers in Islamic Azad University. The Journal of Modern Thoughts in Education. 2010;5(4):11-23[Article in Farsi].

11. Nouraei T, Amirtash AM, Tondnevis F, Behrangi MR. Relationship among Philosophy of Education, Leadership Style of Directors and Organizational Climate in the Colleges and Departments of Physical Education. Journal of Movement Science \& Sports 2006;4(7):37-52[Article in Farsi].

12. Nouraei T, Amirtash AM, Tondnevis F, Behrangi MR. Relationship among Philosophy of Education of Directors and Organizational Climate in Physical Education Department and Colleges in Iran. Research on Sport Science. 2008;6(19):55-69[Article in Farsi].

13. Safania AM, Ghorbanalizadeh FG, Tayebi SM. Teaching Physical Education Principles and Philosophy: Induced a Change in Educational Philosophy Preference from Idealism to Realism. Quarterly Educational Psychology. 2010;6(16):59-75[Article in Farsi].

14. Shahbazi-Dastjerdi R, S.E. M-J. Examining the Relation between Philosophic Mindedness and the Teachers' Teaching Method in High Schools in Isfahan City. Journal of Education (Journal of Education \& Psychology). 2009;5(2):41-58[Article in Farsi].

15. Sokhanvar N, Mahroozade T. Philosophical Mentality and Attitude towards Active Teaching Methods among Middle School Math Teachers. New Thoughts on Education. 2010;6(3):67-94[Article in Farsi].

16. Talebpour M, Hoseini A, Jabari H, Jabari M. Study and Comparison of Physical Mindedness of Managers, Different Sport Team Coaches, Team Supervisors in Iran Universities. Research on Sport Science. 2005;3(7):109-30[Article in Farsi].

17. Wiles JW, Bondi JC. Curriculum Development: A Guide to Practice. 8th ed: Pearson Education, Limited; 2010. $368 \mathrm{p}$.

18. Zandevanian A, Safaei Moghaddam M, Pakseresht MJ, Sepaci H. Recognition and Analysis of the Educational Philosophy of Yazd Province Adult Education Instructors. Journal of Education (Journal of Education \& Psychology). 2009;5(3):3-26[Article in Farsi].

19. Soltani I. Measurement of Managers' Philosophical Mindedness. Tadbir. 1996(62):16-9 [Article in Farsi]. 


\section{اولويت فلسفه آموزشى و ذهنيت فلسفى اعضاى هيأت علمى تربيتبدنى و علوم ورزشى ايران}

\section{'فاطمه قربانعلىزاده قاضيانى، 'سيد محمد حسين رضوى، "سياوش خدايرست سرشكهُ، زروح الله قاسمى حسبن رضو}

$$
\text { ا. كارشناسى ارشد مديريت ورزشى، دانشخاه آزاد اسلامى واحد تهران شمال، تهران، ايران. }
$$

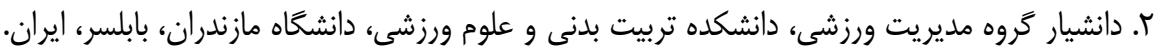

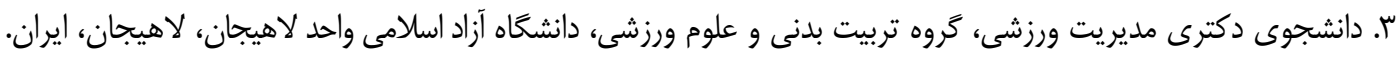

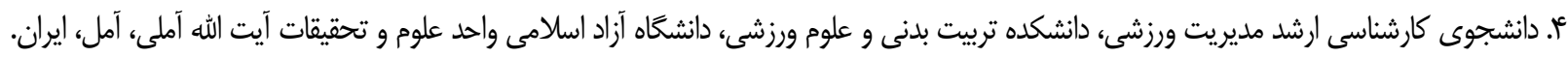

جكيده

هدف از يزوهش حاضر اولويت فلسفه آموزشى و ذهنيت فلسفى هيئات علمى تربيتبدنى و علوم ورزشى ايران بود. • ا1 يرسشنامه بطور تصادفى

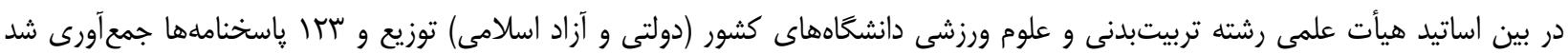

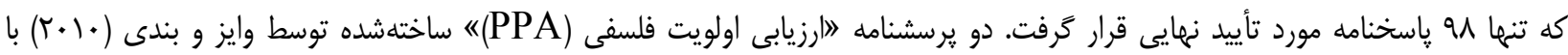

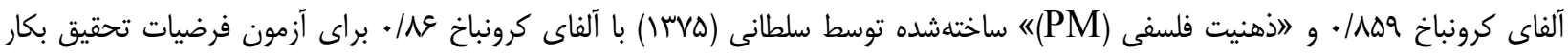

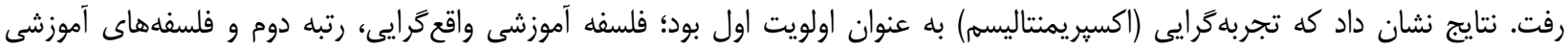

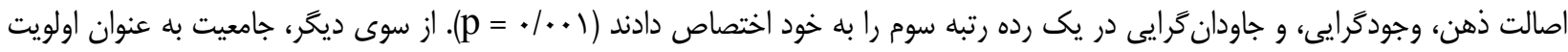

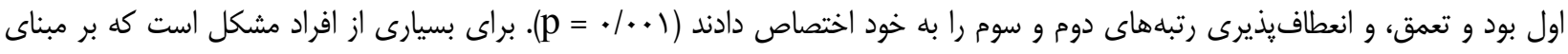

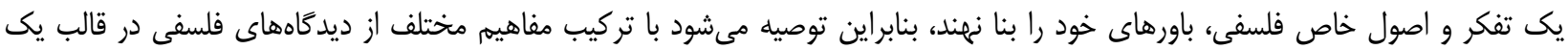

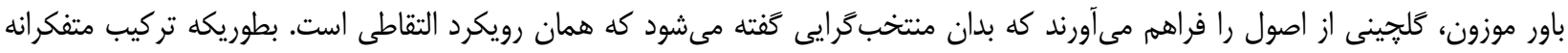

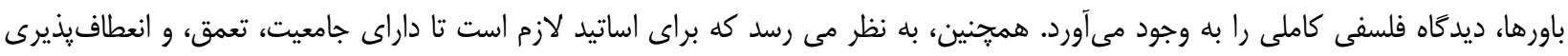

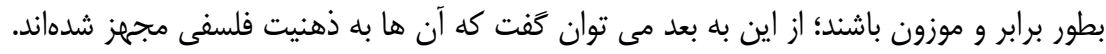

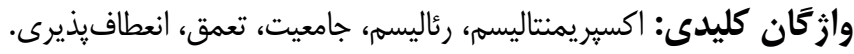

